\title{
Literature Review: HYPERBARIC OXYGEN THERAPY ON MUCORMYCOSIS INFECTION IN ORAL CAVITY
}

\author{
Fanny Margaretha Laihad ${ }^{1}$ I Ketut Sudiana ${ }^{2}$, M Guritno $\mathbf{S}^{3}$ \\ ${ }^{1}$ Faculty of Dentistry, Hang Tuah University, Surabaya, ${ }^{2}$ Faculty of Medicine Airlangga University Surabaya, \\ ${ }^{3}$ Faculty of Medicine UPN University Jakarta
}

\begin{abstract}
ABSTRAK
Infeksi mukormikosis merupakan infeksi jamur yang invasif, akut dan berprogres cepat dengan angka mortalitas yang tinggi kecuali dapat diidentifikasikan dengan segera. Manifestasi oral dari infeksi ini kadang terlihat sebagai ulser di palatal, dan dapat dipicu oleh pencabutan gigi pada maksila maupun mandibular. Terapi oksigen hiperbarik (OHB) adalah pemberian 100\% oksigen murni pada ruangan yang bertekanan lebih dari 1 atmosfir yang dapat digunakan untuk terapi infeksi mukormikosis pada rongga mulut. Tujuan dari makalah ini adalah menganalisis manfaat dari terapi oksigen hiperbarik pada infeksi mukormikosis pada rongga mulut pada 30 jurnal dan satu jurnal tentang kasus yang diduga infeksi mukormikosis setelah pencabutan gigi dari tahun 1980 sampai 2016. Terapi oksigen hiperbarik digunakan hanya sebagai terapi penunjang dan biasanya diberikan setelah pemberian anti jamur dan pembedahan dalam 30 jurnal tetapi pada satu kasus yang diduga infeksi mukormikosis setelah pencabutan gigi, terapi oksigen hiperbarik diberikan lebih awal. Perlu adanya pertimbangan dalam pemberian terapi oksigen hiperbarik lebih awal pada kasus infeksi mukormikosis di rongga mulut yang kemungkinan akan memperbaiki prognosis dan tingkat bertahannya pasien terhadap infeksi ini. (FMI 2017;53:163-168)
\end{abstract}

Kata kunci: Oksigen hiperbarik, Mukormikosis, Rongga mulut.

\begin{abstract}
Mucormycosis infection is an invasive, acute and rapidly progressing fungal infection with high mortality rate unless it was identified promptly. Oral manifestations of these infections, some times appeared as palatal ulcer and can be triggered by tooth extraction on maxilla or mandibula in which the organ is not cured but even damage the gingival and alveolar bone. Hyperbaric oxygen (HBO) therapy is the administration of 100\% pure oxygen in a pressurized room more than 1 atmophere that can be used for therapy of mucormycosis infection in oral cavity. The aim of this study is to analyze the use of hyperbaric oxygen therapy on mucormycosis infections in oral cavity in 30 journals and ljournal of suspected case of mucormycosis infection post dental extraction from 1980 until 2016. Hyperbaric oxygen therapy was used as the last and adjunctive therapy after antifungal and surgery in 30 jounals but in 1 suspected case, hyperbaric oxygen therapy was given earlier. The need for consideration to provide early HBO therapy in case of mucormycosis infection in oral cavity will improve prognosis and survival rate of the patient. (FMI 2017;53:163168)
\end{abstract}

Keywords: Hyperbaric oxygen, Mucormycosis. Oral cavity

Correspondence: Fanny Margaretha Laihad, Faculty of Dentistry, Hang Tuah University, Surabaya. Email: fanny.m.laihad@gmail.com

\section{INTRODUCTION}

Mucormycosis (Zygomycosis, phycomycosis) is an acute opportunistic infection caused by saprophytic fungus class Phycomycetes order Mucorales and family Mucoracae, found in soil, bread molds and decaying fruits and vegetables (Nallapu et al 2015). Rhizopus is predominant pathogen accounting for $90 \%$ of the cases of rhinocerebral mucormycosis. This microbe maybe cultured from the oral cavity, nasal passage, throat and stool of healthy patients witho ut clinical signs of infection (Auluck 2007). Mucormycosis is a rare opportunistic infection and was first described by Paultauf in 1885. It is recognized as one of the most rapidly progressive lethal form of fungal infection in human beings with a high mortality of $70-100 \%$. The most commonly reported form of the disease is rhinocerebral mucormycosis, which is characterized by progressive fungal invasion of the hard palate, paranasal sinuses, orbit, and brain. It can be subdivided into rhinomaxillary and rhino-oculocerebral forms, the latter being characterized by high mortality rate. The conditions predisposing to mucormycosis are diabetes mellitus, malnutrition, haematological malignancies, neutropenia, burns, surgical procedures, occlusive dressings, antibiotics, long-term steroid therapy, and immunosuppressive therapy. Successful management of this fulminant infection requires early recognition of the disease and aggressive medical and surgical intervention to prevent the high morbidity and mortality associated with the 
disease process. Mucormycosis is the third invasive mycosis in order of importance after candidiasis and aspergillosis and is caused by fungi of the class Zygomycetes. The most impotant species in order of frequency is Rhyzopus arrhizus (oryzae) (Garlapatti et al 2014).

Involvement of the oral cavity usually appears as palatal ulceration and later as perforation of the palate as a result of infection in the nasal cavity or paranasal sinuses via palatal vessels. Often there is a history of extraction of a maxillary tooth with pus discharge from an unhealed socket and exposure of necrotic bone or a solitary palatal ulcer with exposed maxillary bone as the sole oral manifestation (Arya et al 2015).

One potential tool for treating invasive fungal infections is hyperbaric oxygen (Segal et al 2007). The use of hyperbaric oxygen as adjunctive treatment for Zygomycosis has been reported since 1970s and hyperbaric oxygen treatment is usually well tolerated and is associated with low risk of adverse events (Tragiannidis and Groll 2009). Hyperbaric oxygen therapy is theoretically attractive because it reverses the ischemic acidotic conditions that perpetuate fungal growth. Hyperbaric oxygen treatments are usually given at two atmospheres for 1 hour on a daily basis for upto 30 treatments. This may limit deformity by decreasing the required area of debridement (Gopalakrishnan 2012). The raised oxygen pressure achieved with HBO treatment seem to improve the capacity of neutrophils to kill organism. In addition, by reversing lactic acidosis, treatment with $\mathrm{HBO}$ complement the oxidative action of Amphotericin B.

HBO therapy for mucormycosis should comprise of exposure to $100 \%$ oxygen, each dive ranging from 90 minutes to 120 minutes at pressures from 2.0 to 2.5 atmospheres with 1 or 2 exposures on a daily basis for total of 40 treatments. Information on treatment of mucormycosis with $\mathrm{HBO}$ is scarce and its role is in doubt (Oswal et al 2012, Reddy et al 2015).

In September 2001, there was one suspected case of mucormycosis infection in Naval Hospital dr. Ramelan Surabaya which was treated with Hyperbaric oxygen therapy without antifungal therapy and have a good result (Laihad et al 2015). Thirty one journals from various countries have been reviewed in 1980 to 2016 , and this data was taken from: In Vivo, J Canada Dental Association, The Internet Journal of Dental Science, La Tunisie Medicale, J Clin Exp Dent, Indian J Dent Res, Otolaryngology Online Journal, Journal of Indian Academy of Oral Medicine and Radiology, Asian Pac J Trop Biomed, Hindrawi Publication corp case reports in Dentistry, OHDM, RJPBCS, Int J Med Public Health,
Saudi Med J, J Oral Maxillofac Pathol, Journal of Oral Medicine, Oral Surgery, Oral Pathology and Oral Radiology, Acta Biomedica Scientia, J Rest Adv Dent, Int J Health Allied Sci, Journal of International Oral Health, The Pan African Medica Journal, Med Oral Pathol Oral Cir Buccal, Antimicrob agents chemother, South Med J, The Laryngoscope, Isr Med Assoc J, Clinical Microbiology and Infection, Medscape Reference and Pinnacle Medicine and Medical Scien-ces.

\section{STANDARD THERAPY ON MUCORMYCOSIS INFECTION IN ORAL CAVITY}

Based on clinical presentation and the involvement of a particular anatomic site, mucormycosis can be divided into at least 6 clinical category: rhinocerebral, pulmonary, cutaneous, gastrointestinal, disseminated and miscellaneous. Four factors are critical for eradicating mucormycosis: rapidly of diagnosis, reversal of the underlying predisposing factors (if possible), appropriate surgical debridement of infected tissue, and appropriate antifungal therapy. When diagnosed early, mucormycosis may be cured by a combination of surgical debridement of the infected area and systemic administration of amphotericin B for up to 3 months. Proper management of the underlying disorder is an important aspect affecting the final outcome of treatment. Prognosis involves high morbidity and mortality and may improve with rapid diagnosis, early management, and reversible underlying risk factors. Survival rates among groups of patients with invasive sinus disease without cerebral involvement may be as high as $50-80 \%$; if infection spreads to the brain, case fatality ratio exceed $80 \%$. The authors propose that oral physician should be aware of the novel perspectives of the disease for early diagnosis and management (Garlapatti et al 2014). Recently intravenous liposomal Amphotericine, intravenous lipid complex and Hyperbaric oxygen therapy has also been used (Vijaya-bala et al 2013)

Segal at al (2007) conducted a retrospective chart review of 14 patients treated with $\mathrm{HBO}$ to evaluate the clinical course and utility of hyperbaric oxygen in patients fungal infections by Mucorales or Aspergillus spp. Most patients had significant immune suppression due to either drug treatment or their underlying disorder. Thirteen of the 14 underwent surgery as part of the treatment and all were receiving antifungal therapy while treated with the hyperbaric oxygen. The number of HBO session range between 1 and 44. Seven of the patients survived the infection. No patient developed complications due to $\mathrm{HBO}$ therapy. Covarrubias et al (2004) made a chart review of mucormycosis patients referred to the $\mathrm{HBO}$ service was performed and $5 \mathrm{mu}$ - 
cormycosis patients referred for HBO had complete charts available. All patients were managed with amphotericin B, surgical debridement and HBO, survival was $60 \%$.

A 62-year-old female presented to the outpatient clinic complaining of pain and swelling of her right cheek. Clinical examinat ion revealed redness and swelling of her right cheek with the presence of fistulous tracts, right facial nerve palsy, and periorbital swelling. Intra oral examination revealed necrotic bare bone of the right side of the hard palate. She gave history of uncontrolled insulin dependent DM, controlled hypertension, liver cirrhosis as a result of hepatitis $\mathrm{C}$ virus, and history of previous FESS (Functional Endoscopy Sinus Surgery). Twenty dives of Hyperbaric oxygen therapy (HBO) under pressure of 2 atmosphere (ATA) with $100 \%$ oxygen saturation were given immediate post operatively and showed signs of clinical improvement. Improvement was noticed during treat-ment as symtoms relieved, swelling subsided, dis-charge stopped, and surgical defect margins showed proper healing with healthy vascularized tissue. One year follow up shows clinical improvement; the tissue margin appear healthy and vascularized. Hyperbaric oxygen (HBO) therapy, has been used in an attempt to control the infection. Experts suggest that $\mathrm{HBO}$ may exercise fungistatic activity by reducing tissue hypoxia and acidosis (Yen et al 2011). Price and Stevents (1980) had reported about Hyper-baric oxygen therapy was utilized in a case of fulminant mucormycosis of the maxilla, orbit and temporal bone and that the patient had refused radical sugery and death seemed imminent in spite of aggressive medical management of diabetic ketoacidosis, Amphotericin B and wide surgical drainage of the maxillary, and eth-moid sinus with orbital decompression.

Hyperbaric oxygen was instituted on the following theoretical premises: 1 . It would provide oxygenation of tissues distal to occluded arteries, thereby increasing local survival and decreasing acidosis. 2. Resultant lessening of acidosis would slow or inhibit rapid growth of the organism and 3. Oxygen in sufficient concentration is fungicidal. The rapid progress of the mucormycosis was arrested. Cultures of tissue prior to hyperbaric oxygen treatment produced heavy growth of Rhizopus and tissues cultured after therapy grew only bacterial contaminants. Hyperbaric therapy has proved to be effective in increasing survival rate (Alfano 2006). Hyperbaric oxygen therapy has also been used to treat mucormycosis (Fogarty et al 2006, Garlapati et al 2014). Hyperbaric oxygen (HBO) therapy, has been used in an attempt to control the infection. Experts suggest that HBO may exercise fungistatic activity by reducing tissue hypoxia and acidosis (Yen et al 2011,
Wadhawan et al 2015). HBO helps in treatment by reducing tissue hypoxia and acidosis caused by vascular invasion of the fungus (Nallapu et al 2015). Although studies have shown that hyperbaric oxygen exerts a fungistatic effect, the most important effect of hyperbaric oxygen is to aid neovascularization, with subsequent healing in poorly perfused acidotic and hypoxic but viable area of tissue (Goel et al 2008). Moreover, treatment with hyperbaric oxygen should also be considered. It is thought to exert a direct fungistatic effect, decreased tissue hypoxia and tissue acidosis. However, the prognosis remains poor with high mortality ranging between 30 and 69\% (Ammari et al 2008). HBO has a direct antifungal effect in vitro through increased production of oxygen-based free radicals. This approach also yields several indirect antimicrobial effect and contribute to tissue healing (Kumar et al 2015). HBO is believed to improve neutrophilic killing by higher oxygen delivery and delaying or totally inhibiting the growth of fungal spores and mycelium (Sujatha et al 2011).

Hyperbaric oxygen therapy has been used as an adjunct to aggressive surgical debridement, amphotericin B therapy, control of any underlying predisposing conditions by aiding neovascularization and subsequent healing (Mohanty et al 2012). Hyperbaric oxygen therapy has been used as an adjunct to aggressive surgical debridement, amphotericin B therapy, control of any underlying predisposing conditions by aiding neovascularization and subsequent healing (Arya et al. 2015) Other treatment modalities include heparinization, avoidance of steroids, oral potassium iodide, supportive care with vitamin supplementation, hyperbaric oxygen therapy, granulocyte colony stimulating factor (G-CSF) and topical application of AmphotericinB (Doni et al 2011). Adjunctive hyperbaric oxygen should also be used when available. Evidence now shows a better prognosis with the use of hyperbaric oxygen, propably because it reserves the hypoxia in local tissues and enhances neutrophil and macrophagekilling ability (Amudhan et al 2014). Hyperbaric oxygen has been used as an adjunct to aggressive surgical debridement, AmB therapy, and control of any underlying predisposing conditions. Although studies have shown that hyperbaric oxygen exerts a fungistatic effect, the most important effect of hyperbaric oxygen is to aid revascularization, with subsequent healing in poorly perfused acidic and hypoxic but viable area of tissue (Kulkarni et al 2015). Adjunctive therapies for mucormycosis in the literature suggest the use of HBO therapy and iron chelating agents that improve the prognosis of this aggressive disease. HBO inhibit fungal growth and promotes the action of Amphotericin B. It is also promotes tissue healing by enchaning the immune respose and improves tissue oxygenation. A review of 
literature showed that patients receiving HBO therapy had higher survival rates provided that the underlying condition is reserved (Motaleb et al 2015). HBO may act as an adjunct in promoting wound healing and increasing phagocytosis (Mengji et al 2015). Hyperbaric oxygen therapy as a supportive therapy have increased the survival 94\% (Ahamed \& Thobaiti 2014)

\section{THERAPY ON SUSPECTED CASE OF MUCORMYCOSIS INFECTION ON DENTAL EXTRACTION}

A female patient was refered from a private practice to the clinic of Oral Surgery Clinic in the Dr. Ramelan Naval Hospital Surabaya. The patient was a 46- yearold and had a big swelling on her left cheek, which was very hard in consistency. This condition also accompanied by difficulty to swallow, facial paresthesia and trismus. The swelling was very painful and the patient could not sleep for days. Five days before she had undergone dental extraction of the second premolar in the left maxilla. She was in good health before the extraction, no systemic diseases and there were no complications from the dental extraction. One day after the extraction, she suffered se vere pain on the cheek and had the above-mentioned symptoms. She came back to the dentist and was given oral antibiotic (Ciprofloxacin 500mg tabs, 3 times daily). Instead of resolving, the swelling enlarged and became more painful. On the left cheek, there was a $2 \mathrm{~cm}$ discolored area, which had a red and blackish complexion (Laihad et al 2015)

The patient had been hospitalized and treated with high dose intravenous antibiotics, among other drugs (pain killers, anti-inflammatory drugs) and had a microscopy, culture and sensitivity test on samples obtained from the swelling. The test indicated Escherecia coli on bacterial culture, which was sensitive to Cefotaxim. The panoramic photo at the time, found no abnormality. After four days of treatment, comprising of Cefotaxim $1 \mathrm{gm}$ iv injection td, combined with Metronidazole 500- mg, twice a day, the patient's condition did not improve (in the order of symptoms, swelling size and her vital signs) so HBO therapy was decided upon. The HBO therapy was given o nce every day in 12 consecutive days. Other drugs was provided to cope with clinical symptoms without antibiotic injection. After HBO treatment through a hole of $1 \mathrm{~cm}$ on the cheek at the red/blackish discolored area (because it was a fibrotic tissue), edema was reduced. HBO promoted wound healing with granulation tissues in the buccal and palatal mucosae which demarcated the necrotic area so a greater part of the involved tissue could be salvaged and restored to normal function. The patient felt very comfortable, did not complain of pain anymore and felt a lot better. She had plastic surgery six months after the treatment and overall made an excellent progress (Laihad et al 2015).

\section{DISCUSSION}

Pressurized hyperoxygenation (i.e. exposure to oxygen at high ambient pressures) greatly increases the oxygen transport capacity in blood and the oxygen pressure gradient across capillary membranes, thereby augmenting tissue oxygenation. This is believed to be beneficial in situation $\mathrm{s}$ of hypoperfusion and anaerobism, and is supported by experimental data that have demonstrated direct antimicrobial activity, restoration or enhancement of cellular defenses, synergistic effects with antimicrobials and restoration or augmentation of tissue repair (Tragiannidis and Groll 2009). HBO can relieve tissue hypoxia, restore oxygen necessary for the granulocyte respiratory burst, restore normal fibroblast function, relieve tissue lactic acidosis and provide oxygen for the oxidative mechanism of Amphotericin B (AMB) (Barratt et al 2001).

In standard treatment of mucormycosis infection in oral cavity is liposomal Amphotericin B as an antifungal therapy and surgical debridement (Mohanty et al 2012). Hyperbaric oxygen was given as the last therapy as a supportive and adjunctive therapy although HBO promoting wound healing and increasing phagocytosis (Mengji et al 2016). HBO is believed to improve neutrophilic killing by higher oxygen delivery and delaying or totally inhibiting the growth of fungal spores and mycelium (Sujatha et al 2011). HBO has a direct antifungal effect in vitro through increased production of oxygen-based free radicals (Kumar et al 2015). HBO inhibit fungal growth and promotes the action of Amphotericin B (Motaleb et al 2015). HBO is a potentially significant adjunct in the treatment of invasive fungal infections. Evidence on its usefulness as a standard of care in these infections is still lacking. Since it will be difficult to generate conclusive data regarding the importance of $\mathrm{HBO}$ in these infections, the value of HBO in these patients should be considered on an individual basis (Segal et al 2007).

In suspected case of mucormycosis infection, $\mathrm{HBO}$ was given earlier (Laihad et al 2015). Early diagnosis of this kind of infection is typically impractical and is challenging due to the following reasons: 1 . Late presentation of the associated symptoms such as pain or fever, as fungal infections does not generally cause an inflammatory process; 2. Extensive tissue and bone necrosis tends to lead the physician to diagnose in terms of osteomyelitis, as it is the most common infection, unless being guide by culture results or by failure of antibiotic therapy; 3 . In general, cultures of the fungus take approximately 
three weeks to confirm and such confirmatory diagnosis is delayed. Hence histopatho-logy of scrape biopsy or tissue biopsy can be promising in early detection of fungi (Ahamed \& Thobaiti 2014). The decision to give the HBO therapy based on the indication of HBO therapy among others is necrotizing soft tissue infection and soft tissue swelling.

\section{CONCLUSION}

HBO played an important role as an initial treatment before antifungals and surgery were undertaken in the suspected case of mucormycosis infection. The need for consideration to provide early HBO therapy in case of mucormycosis infection in oral cavity will improve prognosis and survival rate of the patient.

\section{REFERENCES}

Ahamed SK, Thobaiti YA (2014). Mucormycosis: a challenge for diagnosis and treatment 2 case reports and review of literature. OHDM 13

Alfano C, Chiummariello S, Dessy LA, Bistoni G, Scuderi N (2006). Combine mucormycosis and aspergillosis of the rhinocerebral region. In vivo 20, 311316

Ammari L, Kilani B, Tiouiri H., Kanoun F., Goubontini A., Mnif E., Zouiten F., Chaker E., Chaabane T.B, 2008, Mucormycosis: Four case reports. La Tunisis Medicale; 86 (n 02), 165-168

Amudhan A., Selvamuthukumar SC., Nalini A., Aarthi NV., Hemalatha VT, 2014, Fungal Infection Emerging into oral cavity: A Rare Case Report with Review of literature. Nov - Dec RJPBCS 5, 82

Arya S., Sharanamma B., Patil N., Anitha B., Bhateja S., Basavaraj, 2015, Rhinomaxillary form of mucormycosis causing sinusitis: A rare case report with review of literature. Jounal of oral medicine, Oral surgery, Oral pathology and oral radiology;1(1):39-44

Auluck A (2007). Maxillary necrosis by mucormycosis. A case report and literature review. Med Oral Patol Oral Cir Buccal 12, E360-4

Barratt DM, Meter KV, Asmar P, et al (2001). Hyperbaric oxygen as an adjunct in zygomycosis: randomized controlled trial in a murine model. Antimicrob agents chemother 45, 3601-3602

Covarrubias LG, Barratt DM, Bartlett R, Metzinger S, van Meter K (2002). invasive aspergillosis treated with adjunctive hyperbaric oxygenation: a retrospective clinical series at a single institution. South Med J 95, 450-456

Doni BR, Peerapur BV, Thotappa LH, Hippapargi SB (2011). Sequence of oral manifestation in rhinomaxillary mucormycosis. Indian J Dent Res 22, 331-5
Fogarty C, Regennitter F, Viozzi CF (2006). Invasive fungal infection of the maxilla following dental extraction in a patient with chronic obstructive pulmonary disease. J Can Dent Assoc 72, 149-50

Garlapatti K, Chavva S, Vaddeswarupu RM, Surampudi J (2014). Fulminant mucomycosis involving paranasal sinuses: a rare case report. Case Reports in Dentistry 2014, article ID 465919

Goel S, Palaskar S, Shetty V, Anju (2008). Rhinomaxillary mucormycosis with cerebral extention: a case report and a comprehensive review of literature. The Internet Journal of Dental Science 6

Gopalakrishnan S (2012). Mucormycosis - a case series. Otolaryngology Online Journal 2. 1ssn 22500359

Kulkarni PK, Reddy NB, Shrinivas B, Takkalki VV (2015). Anesthetic considerations in the management of mucormycosis. Int J Med Public Health 5, 387-90

Kumar N, Singh AK, Pandey S, Singh S (2015). Rhinomaxillary osteomyelitis due to mucormycosis in an immunocompromised geriatric patient: a case report with review of treatment options. Int $\mathrm{J}$ Health Allied Sci 4, 160-4

Laihad FM, Sudiana IK, Suryokusumo MG (2015). Case report: the diagnosis, treatment and outcome of a rare case suspected mucormycosis. Pinnacle Medicine \& Medical Sciences 2, Article ID pmms_174,502-505, ISSN:2360-9516

Mengji AK, Yaga US, Gollamudi N, Prakash B, Rajashekar E (2016). Mucormycosis in a surgical defect masquerading as osteomyelitis. The Pan African Medical Journal 23, 16

Mohanty N, Misra SR, Sahoo SR, Mishra S, Vasudevan V, Kailasam S (2012). Rhinomaxillary mucormycosis masquerading as chronic osteomyelitis: a series of four rare cases with review literature. J Indian Aca Oral Med Radiol 24, 315-323

Motaleb HYA, Mohamed MS, Mobarak FA (2015). A fatal outcome of rhino-orbito-cerebral mucormycosis following tooth extraction: a case report. Journal of International Oral Health 7, 1-4

Nallapu V, Vuppalapati HB, Sambhana S, Balasankulu B (2015). Rhinocerebral mucormycosis. Journal of Indian Academy of Oral Medicine \& Radiology 27, 147-151

Oswal NP, Gadre PK, Sathe P, Gadre KS (2012). Mucormycosis of mandible with unfavorable outcome. Case report in dentistry 2012, Article ID 257940

Price JC, Stevens CL (1980). Hyperbaric oxygen in the treatment of rhinocerebral mucormycosis. The laryngoscope 90, 737-47

Reddy MGC, Babu VR, Kumar MD, Rao VE (2015). Mucormycosis: A case report. J Res Adv Dent 4, 2932 
Segal E, Menhusen MJ, Shawn S (2007). Hyperbaric oxygen in the treatment of invasive fungal infections: a single - center experience. Isr Med Assoc J 9, 355-7 Sujatha RS, Rakesh N, Deepa J, Ashish L, Shridevi B (2011). Rhino cerebral mucormycosis. J Clin Exp Dent 3, e256-60

Tragiannidis A, Groll AH (2009). Hyperbaric oxygen therapy and other adjunctive treatments for zygomycosis. Clinical Microbiology and Infection 15, 8286. doi:10.iiii/j.1469-0691.2009.02986.x
Vijayabala GS, Annigeri RG, Sudarshan R (2013). Mucormycosis in a diabetic ketoacidosis patient. Asian Pac. J Trop Biomed 3, 830-833

Wadhawan R, Lustra K, Reddy Y, Solanki G (2015). Mucormycosis; deadlier infection: an overview. Acta Biomedica Scientia 2, 11-15

Yen MT, Cunha BA (2011). Rhinocerebral mucormycosis treatment \& management. Medscape reference: Drug diseases \& Procedures 